WOLTERSTORFF'S REFORMED EPISTEMOLOGY ${ }^{1}$

\author{
Deane-Peter Baker \\ United States Naval Academy \\ Annapolis, Maryland, USA
}

\begin{abstract}
This paper offers an analysis of Nicholas Wolterstorff's contribution to the Reformed epistemology movement, which holds as its central claim the idea that belief in God can, under the appropriate circumstances, be properly basic. In particular this paper addresses Wolterstoff's arguments for his claim that Christian believers are epistemically entitled to their beliefs. The paper begins by setting out Wolterstoff's theory, before articulating the main lines of objection that have been raised against Wolterstorff's arguments. The paper concludes with an analysis of whether or not Wolterstorff's arguments offer genuine support to the Reformed epistemology project.
\end{abstract}

Keywords: Reformed Epistemology, The De Jure Objection to Religious Belief, Religious Experience, Epistemic Entitlement, Epistemic Warrant

\title{
Introduction
}

Despite the distaste with which the claims and arguments of Reformed epistemology are often received by epistemologists in general, it is becoming ever more difficult to ignore this theory of knowledge. Expounded by a vanguard of respected and able philosophers Alvin Plantinga, Nicholas Wolterstorff and William Alston in particular - the declarations of Reformed epistemology, while centred on the idea of knowledge of God, nonetheless make strong claims about epistemology in general. The idea that knowledge of God is possible, in the way that Reformed epistemologists conceive of this knowledge, acts as a particularly difficult test case by which to assess the conditions under which beliefs might be considered justified, or rational, or indeed knowledge.

In an earlier paper in this journal I addressed the contribution of William Alson to the Reformed epistemology project. In that paper I pointed out that the central goal of the arguments offered by Reformed epistemologists is to oppose what Plantinga calls the de jure objection to theistic belief - the idea that it is somehow irrational, a dereliction of epistemic duty, or in some other sense epistemically unacceptable, to believe in God. This objection is distinct from what Plantinga labels the de facto objection - the objection that, whatever the rational status of belief in God, it is, in fact, a false belief. The primary (and limited) goal of Reformed epistemology, then, is to defend Christian belief against the de jure objection, thereby showing that "everything really depends on the truth of Christian belief" (Plantinga 2000:xiii).

\footnotetext{
This material was first published in the author's book, Tayloring Reformed Epistemology: Charles Taylor, Alvin Plantinga and the de jure Challenge to Christian Belief (London: SCM-Canterbury, September 2007). It is published here with permission of SCM-Canterbury Press.
} 
Having shown in my analysis of Alston's contribution of Reformed epistemology that it falls short of properly addressing the de jure objection, in this paper I turn to an analysis of Nicholas Wolterstoff's contribution to the Reformed epistemology project.

\section{Wolterstoff's Theory}

Nicholas Wolterstorff, until recently the Noah Porter Professor of Philosophical Theology at Yale, is widely recognised, along with William Alston and Alvin Plantinga, as one of the leading figures in the Reformed epistemology movement. ${ }^{2}$ Wolterstorff's first foray into the area of the relation between reason and religious faith was his Reason within the Bounds of Religion (1976). The specific focus of that book, however, was on the bearing of Christian faith on the practice of scholarship, and while Hoitenga for one regards this book as important to the Reformed epistemology project (Hoitenga 1991:241), its claims are peripheral rather than central to that project. Wolterstorff's next incursion into this arena came in the book he co-edited with Hendrik Hart and Johan van der Hoeven, entitled Rationality in the Calvinian Tradition. This book, a collection of papers drawn from a conference on the theme of "Rationality in the Calvinian Tradition" which took place in Toronto in 1981, is an interesting early step in the genesis of the Reformed epistemology project. It was the first book to include papers by all three of Reformed epistemology's leading figures - Alston, Plantinga and Wolterstorff - and the first to specifically focus on the concept of rationality within the Calvinist tradition. It did not receive wide recognition, however, and Wolterstorff's contribution, "Thomas Reid on Rationality", was again peripheral to the Reformed epistemology project. ${ }^{3}$ It was not until the publication of Faith and Rationality in 1983, a book edited jointly by Wolterstorff and Plantinga, that Wolterstorff made his first contribution to the central ideas of Reformed epistemology.

Faith and Rationality is a landmark book in the history of contemporary Reformed epistemology. It grew out of a yearlong project entitled "Toward a Reformed View of Faith and Reason" which was supported and directed by the Centre for Christian Studies at Calvin College. While the book is not, strictly speaking, a manifesto for Reformed epistemology, ${ }^{4}$ it comes very close to being one, and the four themes that Wolterstorff picks out (in his introduction to the book) as tying the contributions in the book together, provide a useful first framework within which to place Reformed epistemology.

The first thing that Wolterstorff sees as providing a unique context for the papers in Faith and Rationality is the collapse of what he calls 'classical foundationalism'. Foundationalism, broadly speaking, is the view that beliefs cannot be justified by circles of inference or by an infinite regress of reasons, but must be either justified by inference from other beliefs via a finite chain of reasons, or be intrinsically reasonable. It is the latter class of beliefs, known as 'basic' beliefs, which, provided that they are rationally held, form the

2 Terence Penelhum, for example, writes that "'Reformed epistemology' is the title often given to an influential body of apologetic arguments that have been offered in recent years by a group of Protestant Christian philosophers: in particular by William Alston, Alvin Plantinga and Nicholas Wolterstorff' (Penelhum, 'Reflections on Reformed Epistemology'). While not usually identified as a member of this core group, George Mavrodes deserves at least an honourable mention.

3 Peripheral, but not unimportant. Like Wolterstorff, Plantinga identifies Reid as an important ally, in some respects, to Reformed epistemology (Plantinga 2000a:98-99, 118). Wolterstorff picks up and develops this aspect of his philosophical work in his recent book, Thomas Reid and the Story of Epistemology.

4 Among the papers included in the book are an historical analysis of the collapse of American evangelical academia by George Marsden, a response to the theology of Wolfhart Pannenburg by David Holwerda, and two short stories (which, admittedly, reflect Reformed epistemology themes) by George I Mavrodes. 
proper foundation for knowledge. The classical foundationalist is that theorist who holds that "The foundation of a rational belief-structure will ... contain just two sorts of propositions. It will contain propositions which are self-evident to the person in question propositions which he just sees to be true. $1+1=2$ would be an example of something self-evident to most of us. Second, it will contain propositions about one's states of consciousness which one cannot mistakenly believe to be true (or mistakenly believe to be false). That I am dizzy would be an example" (Wolterstorff 1983a:2-3).

Although he does not argue the point, Wolterstorff takes it as given that classical foundationalism has been thoroughly discredited. ${ }^{5}$ The papers in the volume (and, it seems safe to say, Reformed epistemology in general) exist in the context of this demise. Unlike some responses to the collapse of classical foundationalism, epistemologists of the Reformed persuasion have not concluded, following Richard Rorty and others, that the project of epistemology is a futile one. Nor have they taken the even more radical step proposed by the likes of Paul Feyerabend of taking as meaningless any distinction between rational and non-rational beliefs. Instead these contributors have presented a positive exploration of post- classical foundationalist epistemology and its impact (in particular, but not exclusively) on the centuries-old debate about the relationship between faith - Christian faith in particular - and reason.

The second important contextual parameter Wolterstorff identifies as defining the contributions to Faith and Rationality and to Reformed epistemology in general, is the evidentialist challenge to religious belief that emerged from the European Enlightenment. The Enlightenment's casting off of "the shackles of tradition and superstition" left the voice of reason as the essential guiding voice of the free human being. It is in listening to this voice that the evidentialist challenge emerges. "The challenge can be seen as consisting of two contentions. It was insisted, in the first place, that it would be wrong for a person to accept Christianity, or any other form of theism, unless it was rational for him to do so. And it was insisted, secondly, that it is not rational for a person to do so unless he holds his religious convictions on the basis of other beliefs of his which give to those convictions adequate evidential support. No religion is acceptable unless rational, and no religion is rational unless supported by evidence. That is the evidentialist challenge" (Wolterstorff 1983a:6). The evidentialist challenge is widely perceived, particularly in the contemporary West, to be an overwhelming one for Christian and theistic belief.

Wolterstorff's own contribution to the volume, "Can Belief in God be Rational if it has no Foundations?" is a direct response to the evidentialist challenge. He rejects the reaction to the challenge adopted by many proponents of Christian theism, namely the fideism in which "the believer has thrown in his lot with revelation" and has thereby rejected the claims of rationality, viewing it as 'only a siren tempter' (Wolterstorff 1983b:136). Wolterstorff views this approach as 'profoundly misguided'. His preferred methodology is instead to re-examine the terms of the evidentialist challenge, to see whether it in fact stands up under critical, rational, scrutiny.

Wolterstorff begins his response to the evidentialist challenge by unveiling one if its central points of origin, in the work of John Locke. ${ }^{6}$ He argues that Locke extended the

\footnotetext{
Here Wolterstorff gestures at Plantinga's arguments in support of this belief set out in his contribution to this volume. These will be considered below. There seems to be a certain amount of bravado in this claim by Wolterstorff, for as we shall see below, he still finds it necessary to spend a good deal of attention on refuting the Locke-inspired foundationalism that deigns to label theistic belief as 'irrational'.

6 Wolterstorff takes his assessment of Locke's epistemology further in his recent book, John Locke and the Ethics of Belief.
} 
classical foundationalist epistemology of Descartes to include not just scientia ${ }^{7}$ but all beliefs in general. "If anyone was to believe anything rationally, he had to satisfy the demands of classical foundationalism. Locke noticed that the central claims of Christianity, and of theism generally, are neither self-evident to us nor incorrigible reports of our states of consciousness. And so he insisted that to be rational in holding them we needed evidence for them. If we are to be rational in holding them, they must occur in the superstructure of our system of belief. And concerning the contention that one ought never believe what it is not rational to believe, Locke, as a good precursor of the Enlightenment, seems to have had no doubt whatsoever" (Wolterstorff 1983a:6).

Wolterstorff's counter takes the form of an alternative criterion of rational belief. In its final form, the criterion is as follows:

"A person $S$ is rational in his eluctable and innocently produced belief ${ }^{8} \mathrm{~B} p$ if and only if $S$ does believe $p$, and either:

(i) $S$ neither has nor ought to have adequate reason to cease from believing $p$, and is not rationally obliged to believe that he does have adequate reason to cease; or

(ii) $S$ does have adequate reason to cease from believing $p$ but does not realize that he does, and is rationally justified in that."

Wolterstorff concludes that "... S will have done as well as can rightly be demanded of him in the use of his belief-governing capacities toward the goal of getting more amply in touch with reality if and only if all of his beliefs are innocently produced and none of those is non-rational on this criterion" (Wolterstorff 1983b:168).

With this criterion in place, he returns to his central question - does belief in God satisfy the requirements of rationality? Or, more specifically, is immediate belief in God (i.e. belief not based on evidence or argument) rational? Wolterstorff can see no reason, in the light of his criterion of rational belief, to deny this, and believes that the evidentialist challenge is thus overcome.

The third defining theme of the papers in Faith and Rationality is one I have already discussed, namely their authors' commitment to the Reformed/Calvinist tradition of theology. In this context Wolterstorff explicitly deploys the term 'Reformed epistemology' (Wolterstorff 1983a:7). Finally, the last defining parameter given by Wolterstorff within which Reformed epistemology fits, is that of the 'inevitable pluralism of the academy'. Articulating how Christian philosophers and other academics should respond to this pluralism within academic circles has been an important part of the work of Wolterstorff, Plantinga and others. This is not, however, central to the Reformed epistemology project when considered on its philosophical merits, and will therefore not be a focus of attention in this book.

In his subsequent philosophical career, intermingled with his work on aesthetics and political philosophy, Wolterstorff has produced a number of papers related to Reformed epistemology. ${ }^{9}$ His most significant contribution since Faith and Rationality has, however, been his book Divine Discourse. While not at the heart of Reformed epistemology (that is,

I.e. science, or well-founded belief.

This rather clumsy phrase seems, in the context of Wolterstorff's argument, to refer to something like a 'first impression' belief, that is, a belief not arrived at on the basis of some argument based on the available evidence.

9 Relevant papers include 'The Migration of the Theistic Arguments: From Natural Theology to Evidentialist Apologetics' (1986), 'Evidentialism, Entitled Belief, \& the Gospels' (1989), and 'The Assurance of Faith' (1990). 
not directly concerned with "the immediacy of our knowledge of God"), the arguments of Divine Discourse provide a crucial support for the Reformed epistemology project. Plantinga, for example, seems to recognise this when he takes Wolterstorff's arguments as providing underlying reinforcement for the model of basic or immediate Christian belief articulated in his Warranted Christian Belief (Plantinga 2000:251n; 271n; 377n). Emerging out of his Wilde Lectures at Oxford University in 1993, Wolterstorff's book, as the title suggests, focuses on the cogency of the claim that God speaks. The importance of this is obvious for an epistemic project based in a theological tradition that holds a high view of Christian scripture as God's Word, and which is committed to the idea of God speaking to us by his Word and through his Spirit ${ }^{10}$. As Wolterstorff says, “...many if not most Jews, Christians, and Muslims, if asked to explain why they allow Scripture to form their beliefs - if they do - would say, sooner or later, that they do so because it is the word of God or the revelation of God. So a discussion of divine discourse, along with a discussion of divine revelation, belongs on the agenda of the epistemologist. And as for myself, I will be wanting to ask what a non-evidentialist epistemology of beliefs grounded on divine discourse might look like" (Wolterstorff 1995:15).

All of this is, as I have said, an important support to the core Reformed epistemology project, but is not at the heart of that project. The exception to this is the penultimate chapter of Divine Discourse, "Are we entitled?" At first Wolterstorff suggests, somewhat misleadingly, that the question at hand in that chapter is "does God speak?" (Wolterstorff 1995:261). It soon becomes clear that the title of the chapter is a more apt description, and Wolterstorff confirms this later when he writes that "The topic before us is how we are to appraise that enormous number of humanity's beliefs which consist of believing that God said so-and-so" (Wolterstorff 1995:266). To answer this question Wolterstorff returns again to an analysis of the epistemological model that he contends remains strongly influential in Western thought, particularly in the area of religious belief - the epistemology of John Locke. The similarity of Wolterstorff's response here with that which he put forward in "Can Belief in God be Rational if it Has no Foundations?" twelve years earlier is, not surprisingly, very evident. In Divine Discourse, after gesturing towards Plantinga's notion of epistemic warrant and Alston's concept of justified belief as set out in Perceiving God, Wolterstorff puts the question in terms of Locke's deontic notion of epistemic entitlement are human beings justified in believing that God speaks? The criterion introduced to assess this is as follows: "a person $\mathrm{S}$ is entitled to his belief that $p$ just in case $\mathrm{S}$ believes $p$, and there's no doxastic practice D pertaining to $p$ such that $\mathrm{S}$ ought to have implemented D and S did not, or S ought to have implemented D better than S did" (Wolterstorff 1995:272).

Central to Wolterstorff's contention in favour of this criterion of entitlement is his application of it to the case of Virginia. 'Virginia' is represented by Wolterstorff as a pseudonym for an acquaintance of his, a Christian, "who is a well-established member of the faculty of one of the old, Eastern seaboard universities of the United States" (Wolterstorff 1995:273) and who has claimed to have had the following experience and subsequent beliefs. On a particular day (February 12, 1987), Virginia "suddenly knew with certain knowledge" (Wolterstorff 1995:274) that God had given her a message, made up of seven connected statements that she was to communicate to her pastor. This experience left her 'awe-struck and terrified' for nothing like this had ever happened to her before nor to anyone she knew (Wolterstorff is quick to point out that Virginia neither is nor was an evangelical Christian, and acknowledges that claims of God speaking are commonplace in

10 For the centrality of this idea to the epistemological branch of this theological tradition, see, for example, Plantinga's extended A/C model below. 
such circles). Virginia communicated the message to her pastor, as well as passing on to other members of the church a second message she also experienced as coming from God. Most importantly for Wolterstorff's purposes, though Virginia took the messages to be from God, she also considered the possibility that her experience could be the result of mental illness, and chose to consult a psychologist to ensure that this were not the case:

I met with a psychologist at Harvard Community Health Plan and told her everything that had happened. After listening to my story, she said that these kinds of things happen all the time, and why was I surprised. She suggested a book that I might read, and thanked me profusely for sharing my experience with her. She did not feel that I required any further sessions... (quoted in Wolterstorff 1995:275).

Wolterstorff asks the question whether Virginia is entitled to her belief that God has spoken to her, and applies his criterion of entitlement. As one might expect, Wolterstorff concludes that "...yes; it is possible for an intelligent adult of the modern Western world to believe that God has spoken to him or her. I draw that conclusion because the possibility seems to me to have been actualised in the case of Virginia" (Wolterstorff 1995:280).

\section{Responses to Wolterstorff}

Representative of the responses to Wolterstorff's argument in Chapter 15 of Divine Discourse, "Are We Entitled?", are those put forward by Philip L Quinn (2001) and Michael Levine (1998), both in papers to which Wolterstorff has replied. As Quinn's arguments cover much the same ground as Levine's, and in more depth, I shall concentrate my attention here on Quinn's formulation and only draw on Levine where further insight might be gained.

Quinn focuses first on Wolterstorff's notion of entitlement, which he describes as "part of a family of concepts of epistemic deontology whose logical structure is the same as that of the textbook concept of moral deontology" (Quinn 2001:265). Wolterstorff divides beliefs into three main categories - those that a person ought not to have, those that a person ought to have, and those "for which it is not the case that he ought not to have them" (Wolterstorff 1995:267). These latter beliefs are beliefs that a person is entitled to hold they are epistemically permissible for that person.

The second important point, from Quinn's perspective, is that Wolterstorff, in common with his fellow Reformed epistemologists, accepts the idea that our beliefs are not formed voluntarily. What are in our control, however, are our doxastic practices. Plantinga puts the point well when he writes:

If you offer me $\$ 1,000,000$ to believe that I am under 30 , or even to stop believing that I am over 30, there is no way (short of mind-altering drugs, say) I can collect. Still, this is by no means the whole story ... some of my beliefs are indirectly within my control (in the way in which, for example, my weight is), even if I can't simply decide what to believe and what not to. I can train myself not to assume automatically that people in white coats know what they are talking about, I can train myself to pay more attention to the evidence, to be less credulous and gullible (or less cynical and sceptical), and so on (Plantinga 2000:96).

Wolterstorff argues that we often have an epistemic obligation to make use of such doxastic practices, "so as to form beliefs on a more reliable basis" (Wolterstorff 1995:271).

It is the fact that Virginia fulfils such an epistemic obligation that, in large part, leads Wolterstorff to conclude that she was entitled to believe that God had spoken to her. Having come to believe that God had spoken to her, Virginia nonetheless set in motion a 
specific doxastic practice aimed at ensuring her belief was formed on a reliable basis - she consulted a psychologist. As Wolterstorff puts it, "she seriously entertained the possibility that her experience was a symptom of mental disorder rather than a case of God inwardly appearing to her as speaking, and took steps to check it out" (Wolterstorff 1995:275).

Quinn, however, finds Wolterstorff's account to be unsatisfactory, and the case as expressed to be inconclusive. He imagines a scenario in which the psychologist consulted by Virginia concludes that she has suffered a 'mild delusory episode' but is nonetheless 'perfectly harmless', and on a par with "all those nice people who wander into the office to report receiving communications from space aliens". The psychologist, concerned to move on to those patients in genuine need of help, "tries to reassure Virginia, thanks her for sharing, and then moves briskly on to a case in more urgent need of her immediate attention" (Quinn 2001:267). This scenario is quite compatible with the account that Wolterstorff has given, and so Quinn concludes that not enough detail has been given the reader to entitle her to accept Wolterstorff's claim that Virginia is entitled to her belief that God has spoken to her. Furthermore, even if it were granted that Virginia is entitled to her belief, Quinn points out that there is a difference between Virginia being 'merely entitled' to believe that God has spoken to her, and her being "both entitled and epistemically obligated to believe as she does" (Quinn 2001:268), and he contends that Wolterstorff's approach only shows Virginia to be entitled to her belief, but not obligated to believe as she does.

Levine makes a similar, but perhaps stronger point, which raises a question about just how philosophically illuminating Wolterstorff's notion of entitlement really is. "For all that Wolterstorff has said, the 'Yorkshire Ripper' is also 'entitled' to believe that God spoke to him - and may be correct in his belief. So too may Margaret Thatcher if she believes, as some others undoubtedly believe and are 'entitled' to believe, that God speaks to her. They could have gone to the same Harvard Health Plan psychologist as the woman in Wolterstorff's example, believed they were being commanded by a loving God, and judged that "accepting that the experiences are veridical, have the consequences that one would expect if the experiences were indeed of God speaking" (Levine 1998:15). Levine argues that Wolterstorff's account of entitlement, even if true, "covertly obfuscates the real issue", which is about "objective justification rather than entitlement" (Levine 1998:15).

In both cases the fundamental objection is the same, namely that Wolterstorff's notion of entitlement is not strong enough to achieve the degree of epistemic respectability he desires for Virginia's beliefs. For Quinn what is needed in addition to entitlement is epistemic obligation, while for Levine the missing element is that of 'objective justification'. The claim is that Wolterstorff's notion of epistemic entitlement is too thin a concept to be of real use, for though we might not want to say that Virginia has violated any epistemic duty in believing what she does and might well therefore be in some sense entitled to her belief, nonetheless this is insufficient to showing that the belief is epistemically justified, as this notion of entitlement leaves open the likelihood that people holding what would generally be considered to be bizarre beliefs ${ }^{11}$ are also epistemically entitled to those beliefs.

Even when Wolterstorff's promise of a developed theory of entitlement materialises, there is reason to doubt, on current evidence, that it will advance Reformed epistemology's position particularly far. As pointed out above, his notion of epistemic entitlement is a

11 Quinn's reference to people who believe they have been communicated with by space aliens, and Levine's example of the "Yorkshire Ripper", suggest this interpretation. 
fundamentally deontological notion - that is, it is intended to address the question of whether a believer has fulfilled her epistemic duty in coming to believe some or other belief. Both Quinn and Levine attack Wolterstorff's notion on the same basic point - while it might be acknowledged that some believer $S$ might be entitled to believe $x$, and therefore not be in violation of the ethics of belief, a more important question remains unanswered. That question (and here I offer an interpretation of what Quinn and Levine in fact say) is whether the conditions under which $S$ has come to believe $x$ are such that there is good reason to think that $S$ knows $x$.

An important part of the background to this debate is the confusion in contemporary epistemology around the notion of justification - what Plantinga calls a "blooming, buzzing confusion with respect to justification" (Plantinga 1993:10). Plantinga identifies four central ideas connected to the term justification, Alston (1993) finds at least six. Most fundamentally, though, as Zagzebski (1996:29-43) points out, the confusion in the meaning of the term justification is linked to the usage thereof by internalists and externalists. Generally speaking, internalists use the term to refer to the idea of doing one's epistemic duty, while externalists use 'justification' as the label for that component which, when added to true belief, accounts ${ }^{12}$ for knowledge. Plantinga attempts to overcome this confusion by renaming the externalist version of justification, calling it warrant, and reserving the term justification for the deontological internalist concept.

Wolterstorff is also clearly trying to avoid this confusion by deploying the term 'entitlement', but it is not difficult to see that for Wolterstorff entitlement is very closely allied to the internalist deontological idea of justification. But both Quinn and Levine make it clear that this is simply not the interesting question - their use of space aliens and the Yorkshire ripper strongly suggests that they view this kind of justification as trivial. Put another way, the claim seems to be that Wolterstorff's standard of entitlement, even if achieved, is insufficient to the task of offering de jure justification for beliefs. While it is difficult to express what the de jure requirement is in this case (particularly as this is not a term used by Quinn and Levine), it seems that what is offered is a sort of argument by analogy which claims that it matters not if Christians are entitled to their beliefs in the way Wolterstorff is arguing, because holders of delusional and insane beliefs can be just as entitled to those beliefs, and we clearly think that the latter category of believers are not justified in holding those beliefs, regardless of whether those beliefs turn out to be true. If Wolterstorff's defence of Christian beliefs leaves Christians still in the company of those with obviously mad beliefs, then his notion of entitlement has not done much for the epistemic status of Christian beliefs. Quinn and Levine's arguments seem instead to show the need for something closer to a defence of warranted Christian belief, where warrant is "that, whatever precisely it is, which together with truth makes the difference between knowledge and mere true belief' (Plantinga 1993:3). Perhaps most damning for Wolterstorff's position, Plantinga seems to agree with Quinn and Levine, arguing that responding to criticism of the epistemic status of Christian belief by defending it from the basis of the internalist deontological idea of justification is unsatisfactory, simply because it is too easily answered. Whether Christians are entitled to their beliefs, in the way Wolterstorff understands that notion, simply cannot be what the de jure objection is about. Plantinga asks us to consider a particular Christian believer:

....as far as we can see, her cognitive faculties are functioning properly; she displays no noticeable dysfunction. She is aware of the objections people have made to Christian belief;

12 Barring Gettier problems. 
she has read and reflected on Freud, Marx, and Nietzsche (not to mention Flew, Mackie and Nielsen) and the other critics of Christian or theistic belief; she knows that the world contains many who do not believe as she does. She doesn't believe on the basis of propositional evidence; she therefore believes in the basic way. Can she be justified (in this broadly deontological sense) in believing in God in this way? (Plantinga 2000:100).

Plantinga thinks that it is blatantly obvious that she can be justified (or entitled) in this sense. If she has investigated all the objections to Christian belief that she can lay her hands on, and has found none of them to be compelling, and has also considered the positive arguments for Christian belief, and has found those attractive but also not ultimately compelling, and then goes on believing in this basic way, she cannot for a moment be accused of violating her epistemic duty. "There could be something defective about her, some malfunction not apparent on the surface. She could be mistaken, a victim of illusion or wishful thinking, despite her best efforts. She could be wrong, desperately wrong, pitiably wrong, in thinking these things; nevertheless, she isn't flouting any discernable duty. She is fulfilling her epistemic responsibilities; she is doing her level best; she is justified" (Plantinga 2000:100-101).

This scenario painted by Plantinga bears obvious parallels to Wolterstorff's case of Virginia. In particular both are clearly based on the central presumption of Reformed epistemology, that knowledge of God is immediate, rather than being the result of some kind of inference. The main difference is in what each party thinks their case study achieves - not a lot, according to Plantinga, and in this he is in clear agreement with Quinn and Levine. Immediately after setting out the above-quoted case of the very reasonable Christian believer, he compares it with the (apparently genuine) case of an inmate of Pine Rest Christian Psychiatric Hospital who expressed dissatisfaction at not receiving sufficient credit for having invented a new form of non-sexual human reproduction - primarily involving suspending a woman from a rope and spinning her around at great speed - by which he claimed to have populated Chicago. Plantinga evaluates this case in much the same way as the case of the Christian believer:

Now there is no reason to think this unfortunate man was flouting epistemic duty, or derelict with respect to cognitive requirement, or careless about his epistemic obligations, or cognitively irresponsible. Perhaps he was doing his level best to satisfy those obligations. Indeed, we can imagine that his main goal in life is satisfying his intellectual obligations and carrying out his cognitive duties. Perhaps he was dutiful in excelsis. If so, he was justified in these mad beliefs [and therefore, in Wolterstorff's terms, 'entitled' to them], even if they are mad, and even though they result from cognitive dysfunction (Plantinga 2000:101-102).

Where Plantinga's Christian believer example was close to Wolterstorff's Virginia, this second case seems to make exactly the same point as Quinn's delusional 'space aliens' believer and Levine's Yorkshire Ripper. The point is that Wolterstoff's notion of entitlement simply doesn't do enough to address the de jure objection.

It is hard not to agree with Plantinga that achieving some minimal level of deontological justification is no great shakes, and that gaining this status offers the Christian little protection against those who object (epistemically) to her holding Christian beliefs. The 'real' question, then, seems to be a question about warrant rather than about justification, and on this score Wolterstorff's notion of epistemic entitlement offers very little. This being so, it seems that we will need to look beyond Wolterstorff's contribution to Reformed epistemology if we are to find an epistemic model that meaningfully responds to the de jure challenge. 


\section{BIBLIOGRAPHY}

Alston, W 1991. Perceiving God: The Epistemology of Religious Experience (Ithaca and London: Cornell University Press).

Alston, W 1993. 'Epistemic Desiderata', Philosophy and Phenomenological Research, 53 (3), (527-51).

Hart, H, van der Hoven, J and Wolterstorff, N (eds.) 1983. Rationality in the Calvinian Tradition (Lanham, MD: University Press of America).

Hoitenga, D 1991. Faith and Reason From Plato to Plantinga: An Introduction to Reformed Epistemology (New York: State University Press of New York).

Levine, M 1998. 'God Speak', Religious Studies 34, (1-16).

Penelhum, T [Date unknown] 'Reflections on Reformed Epistemology', web document (http://www.ucalgary.ca/ nurelweb/papers/other/penel.html).

Plantinga, A 1993. Warrant: the Current Debate (New York: Oxford University Press).

Plantinga, A 2000. Warranted Christian Belief (New York and Oxford: Oxford University Press).

Quinn, PL 2001. 'Can God speak? Does God speak?', Religious Studies 37, (259-269).

Wolterstorff, N 1976 ( $2^{\text {nd }}$ ed., 1984). Reason Within the Bounds of Religion (Grand Rapids, MI Eerdmans).

Wolterstorff, N 1983a. 'Introduction', in Plantinga, A and Wolterstorff, N (eds.), Faith and Rationality: Reason and Belief in God (Notre Dame, IN: University of Notre Dame Press), (1-15).

Wolterstorff, N 1983b. 'Can Belief in God Be Rational if it has no Foundations?' in Plantinga, A and Wolterstorff, N (eds.), Faith and Rationality: Reason and Belief in God (Notre Dame, in: University of Notre Dame Press), (135-186).

Wolterstorff, N 1986. 'The Migration of the Theistic Arguments: From Natural Theology to Evidentialist Apologetics', in Audi, R and Wainwright WJ (eds.), Rationality, Religious Belief \& Moral Commitment (Ithaca: Cornell University Press), (38-81).

Wolterstorff, N 1989. 'Evidence, Entitled Belief, and the Gospels', Faith and Philosophy, 6, (429-444).

Wolterstorff, N 1990. 'The Assurance of Faith', Faith and Philosophy, 7, (396-417).

Wolterstorff, N 1995. Divine Discourse (Cambridge: Cambridge University Press).

Wolterstorff, N 2001. Thomas Reid and the Story of Epistemology (Cambridge: Cambridge University Press).

Zagzebski, L 1996. Virtues of the Mind (Cambridge: Cambridge University Press). 